\title{
No Evidence of Adverse Effects on Germination, Emergence, and Fruit Yield due to Space Exposure of Tomato Seeds
}

\author{
Brian A. Kahn ${ }^{1}$ \\ Department of Horticulture and Landscape Architecture, Oklahoma State University, Stillwater, \\ OK 74078-0511
}

\author{
Peter J. Stoffella ${ }^{1}$ \\ Agricultural Research and Education Center, Institute of Food and Agricultural Sciences, University of \\ Florida, 2199 South Rock Road, Fort Pierce, FL 34945-3138
}

Additional index words. Lycopersicon esculentum, long duration exposure facility (LDEF), National Aeronautics and Space Administration, space exposed experiment developed for students (SEEDS), space shuttle

\begin{abstract}
Seeds of 'Rutgers California Supreme' tomato (Lycopersicon esculentum Mill.) were exposed to outer space conditions aboard the long duration exposure facility (LDEF) satellite in the space exposed experiment developed for students (SEEDS) project of the National Aeronautics and Space Administration (NASA). Seeds aboard the LDEF were packed in dacron bags forming four layers per sealed canister. Some of these seeds were used in Oklahoma and Florida for studies of germination, emergence, and fruit yield. Among all measured variables in three experiments, there was only one significant main effect of canister 2 versus canister 7 (for mean time to germination) and only one main effect of layer (for seedling shoot dry weight). There also were only two inconsistent canister $x$ layer interactions in the germination tests. The contrast of Earth-based control seed versus space-exposed seed was significant four times: in Oklahoma in 1991 the mean time to germination of space-exposed seeds and the days to $50 \%$ of final germination were 0.7 days less than for Earth-based seeds, and in Florida in 1992 seedling percent emergence and shoot dry weight were increased by space exposure. Fruit yield and marketability were unaffected in plants grown from space-exposed seeds. These results support student findings from the SEEDS project, and provide evidence that tomato seeds can survive in space for several years without adverse effects on germination, emergence, and fruit yield.
\end{abstract}

The space exposed experiment developed for students (SEEDS) was made available to the academic community in 1990 by the Educational Affairs Division of the National Aeronautics and Space Administration (NASA), the NASA Langley Research Center, and the George W. Park Seed Co., Greenwood, S.C.

The SEEDS project was part of the first mission of the reusable long duration exposure facility (LDEF) satellite. The LDEF acts as a framework for various experiments on the effects of long-term exposure to space conditions (Grigsby et al., 1990). The LDEF is a 12-sided cylinder $9.1 \mathrm{~m}$ long and $4.3 \mathrm{~m}$ in diameter. The LDEF can accommodate a total of 86 experiment trays, and each tray can house several totally self-contained experiments. The LDEF is designed to be placed in orbit by the space shuttle, and it is threeaxis stabilized when free flying in space. This stabilization allows experiments flown on the LDEF to measure the effects of space exposure with respect to any surface orientation, because the sides of the satellite maintain the same position relative to Earth. The SEEDS experiment, designated P0004-2, was placed in tray F-2 near the trailing edge of the LDEF, next to the end pointed toward space (Melton, 1991).

Received for publication 19 June 1995. Accepted for publication 10 Oct. 1995. Approved for publication by the director of the Oklahoma Agricultural Experiment Station. This research was supported in part under Oklahoma project H-2026. Florida Agricultural Experiment Station journal series no. R-04535. The information given in this publication is for educational purposes only. Mention of a trademark, proprietary product, or vendor does not constitute a guarantee or warranty of the product, nor does it imply approval or disapproval to the exclusion of other products or vendors that also may be suitable. The cost of publishing this paper was defrayed in part by the payment of page charges. Under postal regulations, this paper therefore must be hereby marked advertisement solely to indicate this fact.

${ }^{1}$ Professor.
On 19 Oct. 1983, 12.5 million seeds of the open-pollinated 'Rutgers California Supreme' tomato were packed into five experimental aluminum canisters numbered 2, 3, 4, 5, and 7. Canisters were painted white on the top and sides and black on the bottom for thermal control. Each canister was $304 \mathrm{~mm}$ in diameter and 102 mm deep. Each canister was filled with four dacron bags of seeds layered atop each other and designated layers A through D, with layer A being uppermost in the canister. Canisters also contained thermoluminescent passive dosimeters between each layer to measure radiation and a passive thermometer for recording maximum temperature. Each canister was sealed under $101 \mathrm{kPa}$ pressure and $20 \% \mathrm{RH}$, using a covering dome $1.27 \mathrm{~mm}$ thick, and was placed in the F-2 tray. The assembled tray was covered with a teflon thermal blanket and loaded onto the LDEF on 19 Jan. 1984 (Grigsby et al., 1990; Melton, 1991).

The LDEF was launched aboard the space shuttle Challenger, Mission 41-C, on 6 Apr. 1984. The next day, the LDEF was placed into orbit at an altitude of $475 \mathrm{~km}$ for what was projected to be a 1year mission. However, with the Challenger disaster placing the entire Shuttle program on hold, the LDEF remained in space for a prolonged period while its orbit decayed. Finally, on 12 Jan. 1990, the LDEF was retrieved by the crew of the Shuttle Columbia during Mission STS-32 at an altitude of $342 \mathrm{~km}$ (Melton, 1991).

After returning to Earth on 20 Jan. 1990, the LDEF was ferried with the shuttle to the Kennedy Space Center, where it underwent several tests. The first experimental tray, F-2, was not removed until 23 Feb. 1990. A formal canister opening was held at Park Seed Co. on 1 Mar. 1990 after each canister was weighed to verify that no moisture had escaped. Park Seed Co. personnel quickly packaged both the space-exposed and Earth-based seeds (which had been stored in Park's controlled environment of $21 \mathrm{C}, 101 \mathrm{kPa}$, 
and $20 \% \mathrm{RH}$ ) in foil packets of Park's proprietary design. Seed packets then were combined with teacher resource guides and data reporting forms to create SEEDS kits for mailing (Melton, 1991).

The main purpose of the SEEDS project was to stimulate interest in science among students. Nearly all of the 12.5 million space-exposed seeds were used for this purpose. However, through the efforts of Nelson J. Ehrlich of NASA's Aerospace Education Services Program at Oklahoma State Univ., we were able to obtain a limited number of surplus SEEDS kits for our research.

SEEDS kits were not designed to facilitate comparisons between canisters or studies of possible canister $\times$ layer interactions. Therefore, one of our objectives was to determine whether there were detectable effects of position on the LDEF (as represented by different canisters), the null hypothesis being that no such effects would be found. Also, the project report forms provided with the SEEDS kits did not request data on fruit yield or fruit marketability, since the desired date of completion for student investigations was 1 June 1990. Another of our objectives was to provide fruit yield data from replicated field experiments. Therefore, we designed experiments to study the main effects of space exposure, canister, and layer, as well as canister $\times$ layer interactions, on tomato seed germination, seedling emergence, and fruit yield.

\section{Materials and Methods}

The surplus SEEDS kits, available to us contained, by chance, primarily packets from canisters 2 and 7 along with the Earthbased controls. The 1990 Oklahoma tomato growing season was well under way by the time these kits became available, so the sealed foil packets were placed in a cooler at 4C until 1991.

Oklahoma, 1991. A germination test was begun on 31 Mar. 1991. Six plastic petri dishes $(9 \mathrm{~cm}$ in diameter) were prepared with a double layer of filter paper disks in each dish. The top disks were divided into five sectors with a marker. Disks were wetted with 5 $\mathrm{ml}$ of tap water and any excess water was drained off. Each dish then received 10 control seeds and 10 seeds from each of the following space-exposed treatments: canister 2, layer A; canister 2, layer D; canister 7, layer A; and canister 7, layer D. Dishes were sealed with paraffin film and incubated under indirect ambient light on a laboratory bench at 21 to $25 \mathrm{C}$. Germination (defined as radicle protrusion of at least $2 \mathrm{~mm}$ ) was monitored daily. Seeds were removed as they germinated. Germination first was observed on 4 Apr., and dishes were monitored through 14 Apr. Each dish received an additional $2 \mathrm{ml}$ of water on $10 \mathrm{Apr}$. with any excess being drained. The design was a randomized block with six replications.

The germinated seeds were used to grow transplants for a field experiment. However, this experiment was lost to flooding.

Oklahoma, 1992. A germination test was begun on 29 Mar. in the laboratory using the same design and procedures as in 1991, except that seven replications were used. Germination first was observed on 1 Apr., and dishes were monitored through 11 Apr.

Germinated seeds were transported to a greenhouse in separate petri dishes each day from 1-5 Apr. Seeds were sown in peat-lite mix in pressed peat pots (volume per pot $42 \mathrm{~cm}^{3}$; one seed per pot), which were contained in plastic flats (54 pots per flat). Young plants received water and liquid fertilizer $(20 \mathrm{~N}-8.8 \mathrm{P}-16.6 \mathrm{~K})$ as necessary.

A Severn very fine sandy loam [coarse-silty, mixed (calcareous), thermic Typic Udifluvent] at the Vegetable Research Station, Bixby, was prepared with a broadcast, preplant-incorporated application of $51 \mathrm{~N}-22 \mathrm{P}-42 \mathrm{~K}\left(\mathrm{~kg} \cdot \mathrm{ha}^{-1}\right)$, plus trifluralin [2,6-dinitro$N, N$-dipropyl-4-(trifluoromethyl)benzenamine; $\left.560 \mathrm{~g} \cdot \mathrm{ha}^{-1}\right]$ for weed control and diazinon $\{[O, O$-diethyl $O$-[6-methyl-2-(1methylethyl)-4-pyrimidinyl] phosphorothioate; $\left.2.2 \mathrm{~kg} \cdot \mathrm{ha}^{-1}\right\}$ for soil insect control.

Field planting took place on 27 Apr. The design was a randomized block with five replications. Plants grown from seeds germinating on 2 and 3 Apr. were used in replications 1-4 and 5, respectively. Surplus plants were used in perimeter guard rows. Furrows were opened with a push plow at a between-row spacing of $1.8 \mathrm{~m}$. One plant (in its peat pot) was set every $60 \mathrm{~cm}$ within a row; thus, the population was equivalent to 9,259 plants/ha. There were six plants per plot. Plots were arranged back-to-back in tiers that were $7.2 \mathrm{~m}$ long. Each plant received about $200 \mathrm{ml}$ of starter solution providing $1079 \mathrm{~N}-949 \mathrm{P}-895 \mathrm{~K}\left(\mathrm{mg} \cdot \mathrm{liter}^{-1}\right)$, respectively.

Six surplus plants from each treatment also were sampled on 29 Apr. by cutting shoots off at the medium level in the peat pots. Shoots were dried at 49C for 7 days and weighed.

A sidedressing with urea was made on 5 June to supply $\mathrm{N}$ at 45 $\mathrm{kg} \cdot \mathrm{ha}^{-1}$. Insects and foliar pathogens were chemically controlled as required during crop growth. Water was applied as needed by trickle irrigation to prevent drought stress.

Nine harvests were made by hand between 17 July and 13 Aug. as fruit matured. All six plants were harvested per plot. Fruit expressing any red-pink color (breakers or more mature) were harvested, separated into marketable and cull categories, counted and weighed. Fruit that were cracked, misshapen, or diseased (including physiological disorders such as blossom-end rot) were classified as culls.

Florida, 1992. The supply of seeds from layers A and D had been depleted, so the Florida studies were conducted on seeds from layers B and $\mathrm{C}$ in canisters 2 and 7. A germination test was begun on 21 Aug. in the laboratory. The same design and general procedures were used as in Oklahoma in 1991, except that seeds were incubated in darkness in a laboratory bench drawer at 22 26C. Germination first was observed on 23 Aug., and dishes were monitored through 30 Aug. Germinated seeds were moved to a potting area and sown in peat-lite mix in flats with inverted pyramid cells (volume per flat cell $42 \mathrm{~cm}^{3}$; one seed per cell). Flats were placed outdoors in a covered shelter designed to grow transplants.

Additional seeds were sown directly into peat-lite mix in flats with inverted pyramid cells $\left(42 \mathrm{~cm}^{3}\right.$ per flat cell) on $21 \mathrm{Aug}$. for an emergence study. The design was a randomized block with three replications. There were 24 seeds per replication from the control and each space-exposed treatment except for canister 7, layer B, which had 20 seeds per replication due to a limited supply. Flats were maintained outdoors in the same covered shelter as was used for seedlings from the germination test. Emerged seedlings were counted daily for 10 days after sowing.

An Oldsmar fine sand (sandy, siliceous, hyperthermic Alfic Arenic Haplaquod) at the Agricultural Research and Education Center, Fort Pierce, was prepared by forming raised beds $1.1 \mathrm{~m}$ wide and $0.15 \mathrm{~m}$ high spaced $2.1 \mathrm{~m}$ apart (center to center). A $30 \mathrm{~N}-$ $54 \mathrm{P}-25 \mathrm{~K}\left(\mathrm{~kg} \cdot \mathrm{ha}^{-1}\right)$ fertilizer was incorporated into the beds and a $115 \mathrm{~N}-75 \mathrm{P}-227 \mathrm{~K}\left(\mathrm{~kg} \cdot \mathrm{ha}^{-1}\right)$ fertilizer was applied in two bands on the surface of each bed. Beds were then covered with white polyethylene mulch.

Field planting took place on 21 Sept. The design was a randomized block with five replications. Plants were spaced $61 \mathrm{~cm}$ apart within rows, with one row in the center of each bed; thus, the population was equivalent to 7689 plants/ha. There were 12 plants per plot.

Six surplus plants from each treatment also were sampled from flats on 21 Sept. by cutting shoots at the medium level. Shoots were dried at 70C for 3 days and weighed. 
Weeds were controlled by hand within the beds and with paraquat (1,1'-dimethyl-4,4'-bipyridinium salts; $\left.280 \mathrm{~g} \cdot \mathrm{ha}^{-1}\right)$ between the beds. Insects and foliar pathogens were chemically controlled as required during crop growth. Subsurface irrigation was used throughout the experiment to maintain the water table at about $38 \mathrm{~cm}$ below the soil surface.

Harvests were made by hand on 21 and 28 Dec. 1992 and on 4 Jan. 1993 as fruit matured. The eight center plants were harvested in each plot. Harvest procedures and grading standards were similar to those used in Oklahoma.

Data were evaluated by year and location using analysis of variance procedures. Mean time to germination was calculated as $\Sigma$ (days to germination) (no. of seeds germinated on that day)/total no. of seeds germinated (Smith and Millett, 1964). Mean time to emergence was calculated as $\Sigma$ (days to emergence) (no. of seedlings emerged on that day)/total no. of seedlings emerged (Gerson and Honma, 1978). The following orthogonal contrasts were used to compare treatments: control vs. space-exposed seed; canister 2 vs. canister 7; layer A (or B) vs. layer D (or C); and the canister $\times$ layer interaction. When the canister $\times$ layer interaction was significant, means were separated by an interaction least significant difference (not presented).

\section{Results and Discussion}

The space-exposed seeds experienced various abnormal conditions. These included increased gravitational forces during launch and landing, apparent weightlessness in orbit, wide temperature ranges, and increased cosmic radiation (Grigsby et al., 1990). The temperatures inside the SEEDS canisters during space flight ranged from about -23 to $35 \mathrm{C}$ (Grigsby et al., 1990). The dosimeters inside the SEEDS canisters indicated that seeds directly under each canister dome had received 720 rads of radiation exposure (differences between canisters were not reported) (Melton, 1991). Upper layers of seeds shielded lower layers, so the dosimeters under layer D received only 350 rads of radiation. Possible physiological effects of these different radiation levels were unknown.

Table 1. Germination of space-exposed tomato seed in a laboratory, Stillwater, Okla.

\begin{tabular}{|c|c|c|c|c|c|c|}
\hline \multirow[b]{2}{*}{ Treatment $^{\mathrm{y}}$} & \multicolumn{2}{|c|}{$\begin{array}{l}\text { Mean days to } \\
\text { germination }^{z}\end{array}$} & \multicolumn{2}{|c|}{$\begin{array}{l}\text { Days from sowing to } \\
50 \% \text { of final } \\
\text { germination }\end{array}$} & \multicolumn{2}{|c|}{$\begin{array}{c}\text { Final } \\
\text { germination }(\%)\end{array}$} \\
\hline & 1991 & 1992 & 1991 & 1992 & 1991 & 1992 \\
\hline Control & 6.7 & 4.8 & 6.2 & 4.3 & 85.0 & 91.4 \\
\hline $\mathrm{C} 2$, layer A & 6.0 & 4.8 & 5.5 & 4.1 & 76.7 & 91.4 \\
\hline C2, layer D & 5.9 & 4.8 & 5.3 & 4.3 & 85.0 & 88.6 \\
\hline C7, layer A & 6.1 & 4.5 & 5.8 & 4.0 & 91.7 & 82.9 \\
\hline C7, layer D & 6.0 & 4.5 & 5.3 & 4.0 & 78.3 & 85.7 \\
\hline \multicolumn{7}{|l|}{ Contrasts } \\
\hline Control vs. space & $*$ & NS & $*$ & NS & NS & NS \\
\hline $\mathrm{C} 2$ vs. $\mathrm{C} 7$ & NS & NS & NS & NS & NS & NS \\
\hline Layer A vs. layer D & NS & NS & NS & NS & NS & NS \\
\hline Canister $\times$ layer & NS & NS & NS & NS & $*$ & NS \\
\hline
\end{tabular}

$\overline{{ }^{\mathrm{z}} \text { Calculated as } \Sigma \text { (days to germination) (no. of seeds germinated on that day)/total no. of seeds }}$ germinated (Smith and Millett, 1964).

${ }^{{ }^{y}} \mathrm{C}=$ canister containing the seed during space exposure. Layers were within canisters.

Ns, ${ }^{*}$ Nonsignificant or significant at $P \leq 0.05$, respectively.

Table 2. Germination of space-exposed tomato seed in a laboratory and seedling emergence in an outdoor covered shelter, Fort Pierce, Fla., 1992.

\begin{tabular}{|c|c|c|c|c|c|c|}
\hline Treatment $^{\mathrm{z}}$ & $\begin{array}{c}\text { Mean } \\
\text { days to } \\
\text { germination }^{\mathrm{y}}\end{array}$ & $\begin{array}{l}\text { Days from } \\
\text { sowing to } \\
50 \% \text { of final } \\
\text { germination }\end{array}$ & $\begin{array}{c}\text { Final } \\
\text { germination } \\
(\%)\end{array}$ & $\begin{array}{c}\text { Mean } \\
\text { days to } \\
\text { emergence }^{\mathrm{x}}\end{array}$ & $\begin{array}{l}\text { Days from } \\
\text { sowing to } \\
50 \% \text { of final } \\
\text { emergence }\end{array}$ & $\begin{array}{c}\text { Final } \\
\text { emergence } \\
(\%)\end{array}$ \\
\hline Control & 3.0 & 3.0 & 93.3 & 4.7 & 4.3 & 58.3 \\
\hline $\mathrm{C} 2$, layer B & 2.8 & 2.8 & 91.7 & 4.4 & 4.0 & 70.9 \\
\hline $\mathrm{C} 2$, layer $\mathrm{C}$ & 3.1 & 3.0 & 93.3 & 4.7 & 4.3 & 84.7 \\
\hline C7, layer B & 2.9 & 3.0 & 96.7 & 4.6 & 4.0 & 85.0 \\
\hline C7, layer C & 2.8 & 3.0 & 93.3 & 4.9 & 4.0 & 75.0 \\
\hline \multicolumn{7}{|l|}{ Contrasts } \\
\hline Control vs. space & NS & NS & NS & NS & NS & $* *$ \\
\hline $\mathrm{C} 2$ vs. $\mathrm{C} 7$ & $*$ & NS & NS & NS & NS & NS \\
\hline Layer B vs. layer C & NS & NS & NS & NS & NS & NS \\
\hline Canister $\times$ layer & $* *$ & NS & NS & NS & NS & NS \\
\hline
\end{tabular}

${ }^{\mathrm{z}} \mathrm{C}=$ canister containing the seed during space exposure. Layers were within canisters.

y Calculated as $\Sigma$ (days to germination)(no. of seeds germinated on that day)/total no. of seeds germinated (Smith and Millett, 1964).

${ }^{x}$ Calculated as $\Sigma$ (days to emergence)(no. of seedlings emerged on that day)/ total no. of seedlings emerged(Gerson and Honma, 1978).

Ns,*** Nonsignificant or significant at $P \leq 0.05$ or 0.01 , respectively. 
Table 3. Shoot dry weights of tomato seedlings grown from spaceexposed seed in a greenhouse (Stillwater, Okla.) or an outdoor covered shelter (Fort Pierce, Fla.), 1992.

\begin{tabular}{llc}
\hline & \multicolumn{2}{c}{ Shoot dry wt (g/plant) } \\
\cline { 2 - 3 } Treatment $^{\mathrm{z}}$ & Okla. & Fla. \\
\hline Control & 0.27 & 0.29 \\
C2,layer A/B & 0.27 & 0.45 \\
C2,layer D/C & 0.24 & 0.33 \\
C7, layer A/B & 0.26 & 0.52 \\
C7, layer D/C & 0.22 & 0.28 \\
Contrasts & & \\
Control vs. space & NS & $*$ \\
C2 vs. C7 & NS & NS \\
Layer A/B vs. layer D/C & NS & $* *$ \\
Canister $\times$ layer & NS & NS
\end{tabular}

$\overline{{ }^{\mathrm{z}} \mathrm{C}}=$ canister containing the seed during space exposure. Layers (A or D in Oklahoma, $\mathrm{B}$ or $\mathrm{C}$ in Florida) were within canisters.

Ns,**** Nonsignificant or significant at $P \leq 0.05$ or 0.01 , respectively.

Germination tests conducted by Park Seed Co. in March, 1990 suggested that space-exposed seeds germinated $18 \%$ to $30 \%$ faster than control seeds (Melton, 1991). The mean time to germination for space-exposed seeds was 6.0 days vs. 6.7 days for control seeds in our 1991 study (Table 1). Space-exposed seeds also reached $50 \%$ of final germination an average of 0.7 day faster than control seeds in 1991. However, space-exposed and control seeds did not differ in germination responses in 1992 (Tables 1 and 2). Taken together, these results suggest that storage conditions aboard the LDEF were better for maintaining seed vigor than conditions on Earth, perhaps due to lower mean temperatures in space. James et al. (1967) reported that, given equal relative humidities, storage at $10 \mathrm{C}$ was superior to storage at 21 or $32 \mathrm{C}$ for maintaining tomato seed viability. The positive effect of space exposure decreased or disappeared following prolonged earth-based storage of the seeds in our studies.

Canister and layer had few effects on rate of seed germination. Seeds from canister 2 took slightly longer to germinate than seeds from canister 7 in Florida in 1992, but a canister $\times$ layer interaction also was evident (Table 2). Layer had no effect on mean time to germination in canister 7, but seeds from layer $\mathrm{C}$ took longer to germinate than seeds from layer B in canister 2 .

Space-exposed seeds did not differ from control seeds in final germination percentage (Tables 1 and 2 ), but one canister $\times$ layer interaction was evident (Table 1). In Oklahoma in 1991, layer had no effect on final germination percentage in canister 2, but layer A gave a higher germination percentage than layer $\mathrm{D}$ in canister 7 (Table 1).

The seedlot used for the SEEDS project had $89 \%$ germination in 1984 (Grigsby et al., 1990). The average final germination percentage across all three of our studies was $88.3 \%$, indicating that the seeds had lost very little viability over time. Germination tests by participants in the SEEDS project were conducted under very diverse conditions, some of which were less than optimal. Student-reported means for the percentage of seeds germinated 14 days after planting, plus or minus the standard deviation (SD), were $66.3 \pm 23.3$ for space-exposed seeds and $64.6 \pm 23.5$ for control seeds (Melton, 1991). These data were averaged across canisters and layers.

There were no differences in the rate of seedling emergence in the Florida study (Table 2). However, seedlings from spaceexposed seeds attained an average final percentage emergence of $78.9 \%$, compared to $58.3 \%$ for seedlings from control seeds. This apparent greater vigor of young seedlings from space-exposed seeds in Florida carried over into seedling shoot dry weights (Table 3). Shoot dry weights also were higher in seedlings from layer B than in those from layer C in Florida. Treatments did not affect seedling shoot dry weights in Oklahoma (Table 3).

Student reports suggested that seedlings from space-exposed seeds grew faster than control seedlings for the first three or four weeks of growth, but that control seedlings eventually caught up (Melton, 1991). Student-reported means (plus or minus the SD, averaged across canisters and layers) were available only for plant height and width at 56 days after planting. These student data showed that plants from space-exposed seeds were $212 \pm 97$ $\mathrm{mm}$ tall and $120 \pm 44 \mathrm{~mm}$ wide, while plants from control seeds were $209 \pm 97 \mathrm{~mm}$ tall and $119 \pm 44 \mathrm{~mm}$ wide (Melton, 1991).

None of the treatments had a significant effect on fruit yields in our studies (Table 4). Yields were high in Oklahoma relative to those in Florida, but the plant population was higher in Oklahoma than in Florida, and the duration of harvest was almost twice as long in Oklahoma.

Students participating in the SEEDS project were not asked to report yield data (number and/or weight of fruit). However, over 1700 students reported on the percentage of plants producing fruit. Means (plus or minus the SD, averaged across canisters and

Table 4. Fruit yields from tomato plants grown from space-exposed seed in field trials, Stillwater, Okla., and Fort Pierce, Fla., 1992.

\begin{tabular}{|c|c|c|c|c|c|c|c|c|}
\hline \multirow[b]{3}{*}{ Treatment $^{z}$} & \multicolumn{6}{|c|}{ Marketable fruit } & \multirow{2}{*}{\multicolumn{2}{|c|}{$\frac{\text { Cull fruit }}{\left(\mathrm{g} \cdot \mathrm{m}^{-2}\right)}$}} \\
\hline & \multicolumn{2}{|c|}{$\left(\right.$ no. $\left./ \mathrm{m}^{2}\right)$} & \multicolumn{2}{|c|}{$\left(\mathrm{g} \cdot \mathrm{m}^{-2}\right)$} & \multicolumn{2}{|c|}{ (g/fruit) } & & \\
\hline & Okla. & Fla. & Okla. & Fla. & Okla. & Fla. & Okla. & Fla. \\
\hline Control & 48 & 16 & 7294 & 2738 & 151 & 167 & 1939 & 12 \\
\hline $\mathrm{C} 2$, layer $\mathrm{A} / \mathrm{B}$ & 47 & 14 & 7305 & 2374 & 156 & 169 & 1876 & 10 \\
\hline $\mathrm{C} 2$, layer D/C & 43 & 17 & 6698 & 2875 & 155 & 166 & 1901 & 7 \\
\hline C7, layer A/B & 47 & 14 & 7087 & 2325 & 151 & 168 & 1984 & 8 \\
\hline C7, layer D/C & 46 & 14 & 6892 & 2389 & 149 & 169 & 1659 & 6 \\
\hline \multicolumn{9}{|l|}{ Contrasts } \\
\hline Control vs. space & NS & NS & NS & NS & NS & NS & NS & NS \\
\hline $\mathrm{C} 2$ vs. C7 & NS & NS & NS & NS & NS & NS & NS & NS \\
\hline Layer A/B vs. layer D/C & NS & NS & NS & NS & NS & NS & NS & NS \\
\hline Canister $\times$ layer & NS & NS & NS & NS & NS & NS & NS & NS \\
\hline
\end{tabular}

${ }^{\overline{\mathrm{z}}} \mathrm{C}=$ canister containing the seed during space exposure. Layers (A or D in Oklahoma, $\mathrm{B}$ or C in Florida) were within canisters.

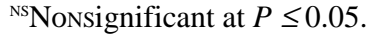


layers) were $74.6 \% \pm 34.2 \%$ for plants from space-exposed seeds and $76.1 \% \pm 33.0 \%$ for plants from control seeds (Melton, 1991).

Limited student data suggested that there were no differences in plant performance due to layers within a given canister (Melton, 1991). Among all measured variables in three experiments, we found only one significant main effect of canister 2 vs. canister 7; only one main effect of layer; and only two, inconsistent canister $\times$ layer interactions. Therefore, position of the seeds on the LDEF and layer of seed storage within canisters were not major factors governing seed and plant response to space exposure.

The student data summaries did not provide statistical evidence for differences in the performance of space-exposed and control seeds (Melton, 1991). Accordingly, our null hypothesis was that we would not find differences. The control vs. space-exposed contrast was significant only four times in our studies, and in each case, the contrast favored the space-exposed seeds. Fruit yield and marketability were unaffected in plants grown from space-ex- posed seeds. We did not detect any obviously mutated plants, although we cannot claim that subtle mutations were not present. We found no evidence of adverse effects on germination, emergence, and fruit yield due to space exposure of tomato seeds.

\section{Literature Cited}

Gerson, R. and S. Honma. 1978. Emergence response of the pepper at low soil temperature. Euphytica 27:151-156.

Grigsby, D.K., N.J. Ehrlich, and J.G. Marlins. 1990. SEEDS (space exposed experiment developed for students) teacher's guide. NASA Publ. PED-114, Wash., D.C.

James, E., L.N. Bass, and D.C. Clark. 1967. Varietal differences in longevity of vegetable seeds and their response to various storage conditions. Proc. Amer. Soc. Hort. Sci. 91:521-528.

Melton, B. 1991. SEEDS: A celebration of science. NASA Publ. EP-281, Wash., D.C.

Smith, P.G. and A.H. Millett. 1964. Germinating and sprouting responses of the tomato at low temperatures. Proc. Amer. Soc. Hort. Sci. 84:480-484. 